\title{
ASSESSMENT OF NOISE POLLUTION IN CHIDAMBARAM TOWN
}

\author{
P.Balashanmugam ${ }^{1}$, A.R.Ramanathan ${ }^{2}$, V.Nehrukumar ${ }^{3}$, K.Balasubramaniyan ${ }^{4}$ \\ ${ }^{1}$ Assistant Professor, ${ }^{2}$ Professor, ${ }^{4}$ Research scholar, Mechanical Engineering, Annamalai University, Tamilnadu, India, \\ ${ }^{3}$ Professor, Civil Engineering, Annamalai University, Tamilnadu, India, \\ pbsapme1980@gmail.com
}

\begin{abstract}
Noise generally is known as unwanted and unwelcome sound. It is considered as the most pervasive pollutant besides the emission pollutants. Along with the increasing degree of air and water pollution, noise pollution is also emerging as a new threat to the inhabitants of Chidambaram town. Noise pollution generated from vehicles with its influence on life quality and the environment may be considered as a hot topic in scientific research and one of the main concerns of the world, especially in urban areas. Motorized traffic is one of the major sources of noise pollution in urban areas. Ambient noise level monitoring was carried out at various locations of the Chidambaram town during 2011(September-November).The data obtained was used to compute various noise parameters, namely equivalent continuous level $\left(L_{e q}\right)$, Noise pollution level $\left(L_{n p}\right)$, Noise climate $(N C)$, Percentile noise levels $\left(L_{10}\right.$, $L_{50}$, $\left.L_{90}\right)$.The comparison of the data shows that the noise levels at various locations of the Chidambaram town are more than the permissible limits. Vehicular traffic and air horns are found to be the main reasons for these high noise levels. This study examines the problems of reduction of individual's efficiency in his/her respective working places because of road traffic noise pollution in Chidambaram due to rapidly growing vehicular traffic. This paper deals with monitoring of the disturbances caused due to vehicular road traffic interrupted by traffic flow conditions on personal work performance. Traffic volume count and noise indices data were collected simultaneously at ten selected sites of the town. The noise level values for exceeded the standards set by the central pollution control board.
\end{abstract}

Index Terms: Ambient noise, level, Noise pollution, Noise climate, dB (A) decibel, Vehicular traffic. $* * *$

\section{INTRODUCTION}

Chidambaram is an ancient famous temple town of the Lord Nataraja (Siva) in Hindu, Religion. It is most important holy and pilgrimage center attracting tourists, coming from all over India and Abroad. The town is named after the temple called "Chit Saba". On the other hand, Chidambaram (i.e. Music Hall or Hall of wisdom) The temple Nataraja was built during the $6-8^{\text {th }}$ centuries after which it was historically influenced and place of sanctity of divine Lord Siva by devoting service of Chola, Pandya, and Vijayanagara Kings during their regime. The Saivate Saint Thiru Manickavasagar, who visited this place and made miracles, fascinating public in the part of divinity, enlightened the Shine of divine Sanctity. This town is called "Thillai as sung in Saiva Puranas. Since the place was Thillai forest and in later stage it is called as Margali (December) is celebrated every year, fascinating devotes from all over India and abroad. The temples at Kalahasti, Kanchipuram, and Chidambaram all stand on a straight line at 79' 45" east longitude.

The Chidambaram temple houses the Akasha Lingam of Shiva and is considered one of the greatest Shiva Temples of Tamil Nadu. Chidambaram hosts the most ancient set of the 108Karana stone carvings, the key dance movements of Nataraja. The temple complex is spread over 40 acres
$(160,000 \mathrm{~m} 2)$ in the heart of the city. Many thousands of devotees come to this auspicious temple to pay homage to the dancing Siva. The temple houses the Shiva and Vishnu in the same complex, where a devotee can have darshan of Lord Shiva and Lord Govindaraja (Lord Vishnu) from a single place. The Govindaraja temple is also among the 108 dhivya desams of Vaishnavites. The famous Natyanjali festival is held in the Nataraja temple complex every year during Maha Shivaratri. Bharatanatyam dancers from different parts of the world offer their prayers to Lord Nataraja and perform in the temple complex.

Noise is an unwanted sound experienced and it is a common condition in Lagos metropolis. An important factor for the life quality in urban centres is related to the noise levels to which the population is submitted. Several factors interfere with the amount of noise pollution throughout the city. A major challenge is the quantification of the noise effects on the population. Growth in terms of economic, social development and population increases the tendency towards increasing noise generation. Considering the connectivity of vicinity, transport routes could result to an increase in noise volume generated. Noise is considered a growing health threat, Hardoy, J.E. Mutlin D., and Satterrhwaite, D. (1992) and if, left unchecked could result to hazardous conditions. In the 
face of unplanned traffic route control, there is an increase in density of traffic, and a resultant increase in noise level (Sukru, 2006). Various land use activities along these routes contribute to vehicular noise generation. Considering that a significant number of these routes are within residential areas, there is the possibility of people at risk of the silent killer called noise. Noise pollution can be considered as an environmental hazard. Noise generally is an unwanted sound effect. The noise originates from human activities, especially the urbanization and the development of transportation and industries. However, the urban population is much more affected by such pollution; however, small town/villages along roadsides or industries are also victim of this problem. Noise is becoming an increasingly omnipresent, yet unnoticed form of pollution even in developed countries. According to Birgitta and Lindvall (1995), road traffic, jet planes, garbage trucks, construction equipment, manufacturing processes, and lawn mowers are some of the major sources of this unwanted sounds that are routinely broadcasted into the air. Though noise pollution is a slow and subtle killer, yet very little efforts have been made to reduce it. Noise, along with other types of pollution has become a hazard to quality of life all over the world. Kiernan (1997) finds that an even relatively low level of noise affects human health adversely. It may cause hypertension, disrupt sleep and hinder cognitive development in children. The effects of excessive noise could be so severe that, there is either a permanent loss of memory or a psychiatric disorder (Bond, 1996). Thus, there are many adverse effects of excessive noise or sudden exposure to noise. The generation of noise is from various sources especially in an urban environment. From industrial to occupational, generation can be at a peak at proximity to airports and national or local authorities to provide an acceptable noise environment for their specific conditions normally devise transport routes especially at T-junctions and bus stops along major transport routes (Chigboh, 2006) .Environmental noise exposure standards and legislation. The standard guideline for the control of noise states that residential institutional and educational institutions should not be over 55dBA between $7 \mathrm{am}$ and $11 \mathrm{pm}$ and $45 \mathrm{dBA}$ between $11 \mathrm{pm}$ till $7 \mathrm{am}$, while industrial and commercial exposure should not be over 70dBA all time (IFC,2007). In some places, these standards are usually not complied with, especially in major urban centre's, exposing people to the risk of noise discomfort. A report published by Stockholm University for the World Health Organization in 1995 has concluded that noise levels outside dwellings should not exceed $55 \mathrm{~dB}(\mathrm{~A})$ to protect the majority of people from being seriously annoyed, and that $50 \mathrm{~dB}(\mathrm{~A})$ should be considered the maximum desirable. In 1999, the World Health Organization concluded that the available evidence showed that noise has been associated with cardiovascular health problems, and there is a relationship between long-term noise exposure above 67-70 dB (A) and hypertension. (Berglund B. Lindvall, T. Schwell, D. (1999). Noise is derived from the Latin word "nausea" implying 'unwanted sound' or 'sound that is loud, unpleasant, or unexpected'. The noise originates from human activities, especially the urbanization and the development of transport and industry. However, the urban population is much more affected by such pollution; however, small town/villages along side roads or industries are also victim of this problem. Noise is becoming an increasingly omnipresent, yet unnoticed form of pollution even in developed countries.

\subsection{SOURCES OF NOISE POLLUTION}

Noise disrupts the tranquility of the environment and can affect climate and human health negatively. Amongst the common sources of noise pollution that contributed directly to climate change are:

\section{(a) Electricity Generating Plant}

Electric energy occupies the top grade in energy hierarchy as it finds innumerable uses in homes, industry, agriculture, and defense and of course in some nations, transportation. Nigeria's electricity power situation is very poor because of erratic power supply. As a result, there is an upsurge in the use of electricity generating plant with its attendant noise pollution on the environment and human health. Most workplaces and homes use generating plants 24 hours in alternative to power supply (Akinbulire et. al 2007). The noise from generating plants in Nigeria couples with its accompanying smoke emission to the sky has greatly contributed to the breaking of the ozone layer in the sky (Olokooba, S.M et al 2005).

\section{(b) Vehicular Traffic}

Increase in vehicular traffic is also a source of noise pollution around the globe especially in most urban cities around the world. The situation is getting seriously alarming with increase in traffic density on city roads (ibid). The emissions of smoke from cars are of great concern to the changes we are currently experiencing in the climate of this country and that of the world in general.

\section{(c) Construction /Industrial Noise}

To meet the demands of the necessity of living, the construction of buildings, highways, and city streets causes a lot of noise. Pneumatic hammers, air compressors, bulldozers, loaders, dump trucks, and pavement breakers are the major sources of noise pollution in construction sites all emitted one classes of smoke or another, which are all contributing to the current changes in climate (ibid).

\section{(d)Household Noise:}

Household equipments such as vacuum cleaners, mixers and some kitchen appliances are noisemakers of the house. Though they do not cause too much of problem, their effect of noise emitted on human health cannot be neglected. 
Furthermore, noise can be generated from neighborhood noise consisting of neighboring apartments and noise within one's own apartment (Niemann H et al 2009).

\section{PREVIOUS WORK}

Thangadurai N, etc.al (2005) discussed the results obtained in a study on environmental noise pollution in the city of Salem. Road traffic noise has been a major contributor to the annoyance, which is substantiated by the result of continuous monitoring of noise equivalent levels $\left(\mathrm{L}_{\mathrm{eq}}\right)$ at a number of silence, residential, commercial, industrial zones and road intersections.Tiwari Divya et.al (2005) Paper assesses the intensity of noise in different zones of the Kanpur city. A critical perusal of the data obtained with the mandatory values revealed that most of the zones surveyed are under the threat of noise menace. Paper also refers the legal options available to counteract this menace.

Jeba Rajasekhar RV, etc.al (2005) estimated either noise levels exceed or are about to cross the permissible standards at most of the sampling sites of current concern in the city. In addition, a simple noise model in the current assessment predicts the ambient noise level Leq and the predicted values are compared with the experimental noise levels. As the predicted values are in reasonable agreement with the estimated values of noise levels, it can be concluded that the modeling equations of present study can be used to predict the noise levels all over the city.

Pachpande BG, et.al (2005) reported that the hearing status and audiometric analysis of school teachers and students was collected from the schools located in the near vicinity of NH-6 passing through Jalgaon city. About 84\% teachers and 92\% students have reported hearing difficulty in the questionnaire. In the audiometric testing mild hearing loss (25 to $35 \mathrm{dBHL}$ ) was observed in both the subject groups. The strategies need to adopt for protection of the teachers/students from the noise exposure are suggested.

Banerjee D, etc.al (2006) revealed that nighttime noise levels $(10.00 \mathrm{pm}-6.00 \mathrm{am})$ in all the locations exceeded the limit prescribed by Central Pollution Control Board. The daytime noise level was much higher at all locations in respect to the nighttime noise level. The Day-Night equivalent noise level (Ldn) was determined and ranged between $67.16 \mathrm{~dB}(\mathrm{~A})$ and 89.44 dB (A).Kisku GC, etc.al (2006) Studied 12 locations with sound level meter to assess day time and night time noise levels of Lucknow city. In residential areas, noise ranged between 67.7 to 78.9 and 52.9 to 56.4 ; in commercial cum traffic areas 74.8 to 84.2 and 68.2 to 74.9 and in industrial areas 76.9-77.2 and 72.2-73.1 dB (A) during day and night time respectively, Values were higher than their prescribed standards, which may pose a significant impact on quality of life.
Thakur Gulab Singh, etc.al (2006) discussed the results of a study undertaken to assess the noise levels at the major traffic junctions and community area near an educational institution of an urban city. Noise equivalent level $\mathrm{L}_{\mathrm{eq}}$ and the statistical levels $\mathrm{L}_{10}, \mathrm{~L}_{50}, \mathrm{~L}_{90}$ were measured in the neighborhood community areas as well as at the traffic junctions. The study indicates a need for proper land-use planning when traffic corridors are built in the silence zone areas.

\section{MATERIALS AND METHODS}

Noise measurements was carried out in eight locations of Chidambaram town representing silent, commercial and residential zones using YF-20 sound level meter. Noise levels were measured at Chidambaram bus stand, Pachaiyappa School, South Car Street (National shopping complex), West car street (Kanchi thotti corner), Sirkazhi main road, Omakulam, O.P.Road (Near Medical College),Government Hospital, Government Higher secondary school and Annamalai university campus. Pachaiyappa School, Government Hospital, Government Higher secondary school, and O.P.Road (Near Medical College) represented the silence zone. Chidambaram bus stand and South Car Street (National shopping complex) and West Car Street (Kanchi thotti corner) were selected for the present study to assess the noise level of commercial zone. Commercial zone is fully occupied with several types of business establishments. Sirkazhi main road, Omakulam, and Annamalai university campus represented the residential area for the study. Initial assessment was made at all the locations by recording sound pressure levels for ten hours (10.00AM to $08.00 \mathrm{PM}$ ) at the interval of one hour in each location.

The present investigation on evaluation and analysis of environmental noise pollution was conducted in the town of Chidambaram during the period of winter season (September to November). Table 1 shows the data on Chidambaram town in context to demography, geographic locations and meteorological aspects during the course of study. Table 2 and Figure 1 depict the ten sampling locations/zones of Chidambaram town that were selected for noise pollution study. The meter was held 1.3 to $1.5 \mathrm{~m}$ above the ground surface and 3.0 to $3.5 \mathrm{~m}$ away from reflecting surface, if any. For each sampling location, noise measurements were carried out continuously for the period of ten days with eight hours of monitoring per day with a gap of one hour after every hour of reading. The schedule selected during the day time was as follows: morning 10.00-11.00 a.m.,11.00a.m-12.00noon, afternoon 12.00-1.00 p.m.,1.00-2.00p.m., 2.00-3.00 p.m.,3.004.00p.m., evening 4.00-5.00 p.m., 5.00-6.00p.m.,6.00-7.00 p.m. and 7.00-8.00p.m. The night readings acted as a control. For each hour, the noise levels were recorded after every two minutes (i.e. 30 readings were recorded every hour). So several numbers of primary raw data were obtained in one spot itself. Obtained raw data were pooled together and classified as morning, afternoon, and evening sound levels. 
The data collected from each location was processed for statistical analysis. All the noise monitoring experiments were carried out under ideal meteorological conditions. Selected sampling locations for noise pollution monitoring in Chidambaram town is given in the table 2 .

Table 1 Area of study and measurement of noise

\begin{tabular}{|c|c|c|}
\hline Sl.no & Parameters & Documented values \\
\hline 1 & $\begin{array}{l}\text { Population(2011 } \\
\text { census) }\end{array}$ & 82,458 \\
\hline 2 & $\begin{array}{l}\text { Geographical } \\
\text { area }\left(\mathrm{km}^{2}\right)\end{array}$ & $4.80 \mathrm{Km}^{2}$ \\
\hline 3 & Population density & 12,052.8in h/sq.km \\
\hline 4 & Latitude & $11.4^{\circ} \mathrm{N}$ \\
\hline 5 & Longitude & $79.7^{\circ} \mathrm{E}$ \\
\hline 6 & Mean sea level & $3 \mathrm{~m}$ above the sea level \\
\hline 7 & Annual rainfall $(\mathrm{mm})$ & $170 \mathrm{~mm}$ \\
\hline 8 & $\begin{array}{l}\text { Max.temperature } \\
\text { during winter in }{ }^{\circ} \mathrm{C}\end{array}$ & $37^{\circ} \mathrm{C}$ \\
\hline 9 & $\begin{array}{l}\text { Min.temperature } \\
\text { during winter in }{ }^{\circ} \mathrm{C}\end{array}$ & $21^{\circ} \mathrm{C}$ \\
\hline 10 & Humidity (\%) & $49.2 \%$ \\
\hline 11 & Wind speed $(\mathrm{km} / \mathrm{hr})$ & $12 \mathrm{mph}$ \\
\hline
\end{tabular}

Average, maximum, and minimum values were calculated and compared with standards prescribed by the Central Pollution Control Board. To measure the environmental noise levels and to assess the noise pollution in the Chidambaram town predominantly due to traffic mobility, the standard procedure using calibrated sound pressure level meter was used. This instrument is primarily designed for community noise surveys. Measurements from 30-130 dB (A) can be carried out with this instrument. Noise measurements were taken following the prescribed procedure stipulated in the manual of the manufacturer of Sound Pressure Level meter. In order to identify the magnitude of increased level of sound than the ambient permissible sound level the percent increase was also calculated and incorporated in the results. Table 3. Shows the Environmental noise standards as prescribed by Central Pollution Control Board (CPCB), New Delhi, India
Table2 Sampling location for noise pollution monitoring in Chidambaram town

\begin{tabular}{|c|c|c|}
\hline Sl.no & Zone(Location name) & Code \\
\hline \multirow{5}{*}{1} & Silence zone & \\
\hline & Pachaiyappa;s school & S1 \\
\hline & Government Hospital & $\mathrm{S} 2$ \\
\hline & $\begin{array}{l}\text { Government Higher secondary } \\
\text { school }\end{array}$ & S3 \\
\hline & O.P.Road(Medical college) & S4 \\
\hline \multirow{4}{*}{2} & Commercial zone & \\
\hline & Bus Stand & $\mathrm{C} 1$ \\
\hline & $\begin{array}{l}\text { South car street(National } \\
\text { shopping) }\end{array}$ & $\mathrm{C} 2$ \\
\hline & West car street & $\mathrm{C} 3$ \\
\hline \multirow{4}{*}{3} & Residential zone & \\
\hline & Sirkazhi main road & $\mathrm{R} 1$ \\
\hline & Omakulam & $\mathrm{R} 2$ \\
\hline & $\begin{array}{l}\text { Annamalai Nagar(University } \\
\text { campus) }\end{array}$ & R3 \\
\hline
\end{tabular}

$\mathrm{S}$-Sensitive areas, C-Commercial areas, R-Residential areas

Table3. Environmental noise standards as prescribed by Central Pollution Control Board (CPCB), New Delhi, India

\begin{tabular}{|c|l|c|c|}
\hline Area code & Type of area & \multicolumn{2}{|c|}{$\begin{array}{l}\text { Environmental noise } \\
\text { standards (Leq) in dB(A) }\end{array}$} \\
\cline { 3 - 4 } & & Day time & Night time \\
\hline A & Industrial area & 75 & 65 \\
\hline B & $\begin{array}{l}\text { Commercial } \\
\text { area }\end{array}$ & 65 & 55 \\
\hline C & Residential area & 55 & 45 \\
\hline D & Silence area & 50 & 40 \\
\hline
\end{tabular}

Notes: Daytime shall mean from 6.00 a.m. to 10.00 p.m.; Nighttime shall mean from 10.00 a.m. to 6.00 a.m.; Silence zone is defined as an area comprising not less than 100 metres around hospitals, educational institutions and courts. The silence zones are zones that are declared as such by the competent authority; mixed categories of areas may be declared as one of the four above-mentioned categories by the competent authority. 


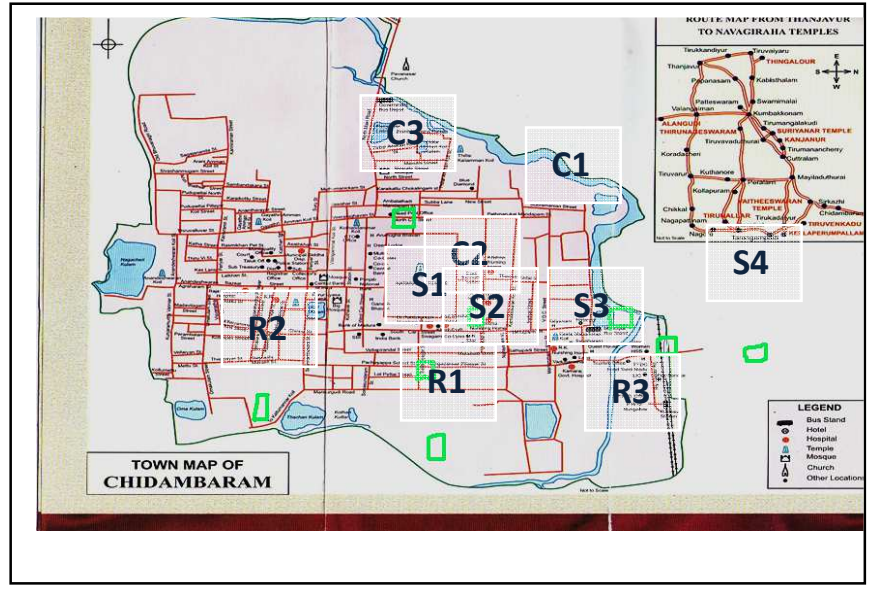

Figure 1.Study area map of Chidambaram town

\section{RESULTS AND DISCUSSION}

The present study establishes that need of awareness regarding adverse impact of noise amongst the public. During the preliminary survey of noise level at different locations, all the locations recorded the standard permissible limit values higher than that of Standards. It was observed that in these locations the noise level varies considerably due to the high volume of traffic flow and commercial activities.

\subsection{Silence Zone}

None of the places in the silence zone recorded noise level below the prescribed limit set by the CPCB (refer table 3). The lowest values recorded was $42 \mathrm{~dB}$ (A) in government Higher secondary school. The educational institutions are exposed to very high noise levels, which might cause nuisance to the students in addition to the adverse health effects. Government girl's higher secondary school is located at one of the busiest roads in Chidambaram and is the highly affected one. The railway station, railway track, marriage halls are also nearer to the school.

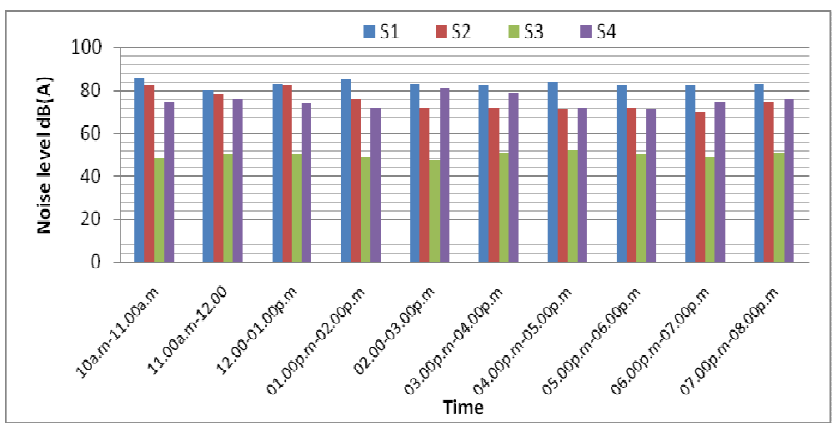

Figure2. Average ambient noise levels in $\mathrm{dB}(\mathrm{A})$ during September 2011(Sensitive areas)
The average Leq for the day is obtained as $64 \mathrm{~d} \mathrm{~B} \mathrm{(A).By}$ virtue of its location, the school is exposed to high noise levels. The average noise level during September 2011, October 2011 and November 2011 is shown in figures 2,3and4 respectively.

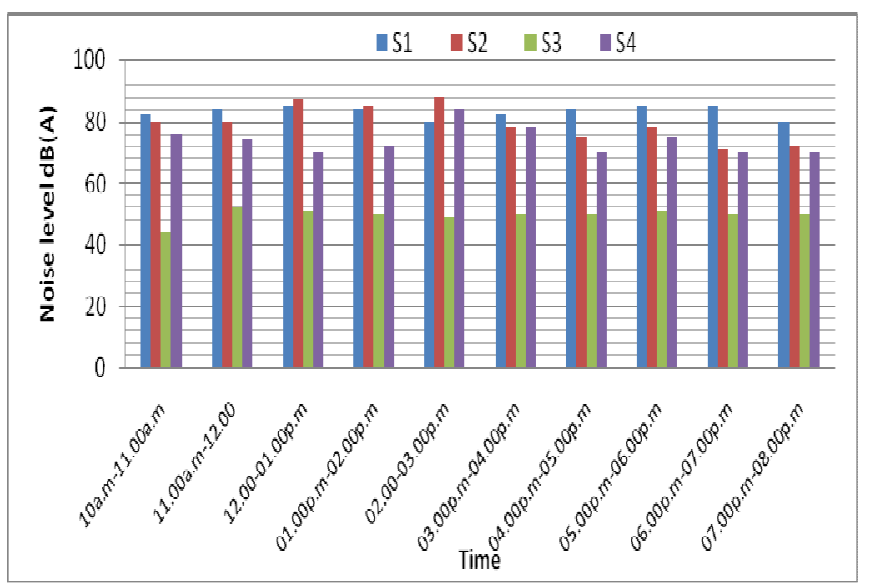

Figure 3.Average ambient noise levels in $\mathrm{dB}(\mathrm{A})$ during October 2011(Sensitive areas)

Noise levels recorded in all the sites of silence zone exceeded the prescribed standard level of $50 \mathrm{~dB}(\mathrm{~A})$. All the places selected under silence zone had noise level above the permissible limit set by CPCB. The average noise level at Pachaiyappa's school ranged between 50.66 \& $86.66 \mathrm{~dB}$ (A). The noise level at Government hospital was recorded between $54.33 \& 88.33 \mathrm{~dB}(\mathrm{~A})$. The noise level at Government higher school was recorded between $45.3 \& 51.63 \mathrm{~dB}$ (A). The noise level at O.P.road (Medical College) was recorded between $54 \& 82 \mathrm{~dB}(\mathrm{~A})$.

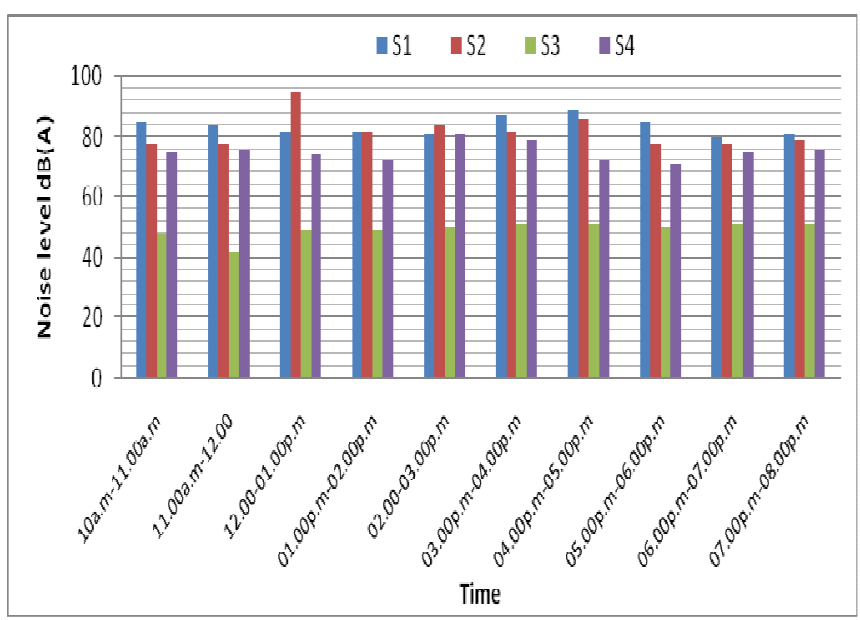

Figure 4. Average ambient noise levels in $\mathrm{dB}(\mathrm{A})$ during November 2011(Sensitive areas) 


\subsection{Commercial Zone}

All the places under commercial zone recorded fairly higher noise level than the prescribed standard limit. The average noise level at Bus stand ranged between 86and 101d B(A). The average noise level at south car street ranged between 55 and $95 \mathrm{~d} \mathrm{~B}(\mathrm{~A})$ and it was between 62 and $88 \mathrm{~d} \mathrm{~B}(\mathrm{~A})$ at west car street. The average noise level during September 2011, October 2011 and November 2011 is shown in figures 5,6 and 7 respectively.

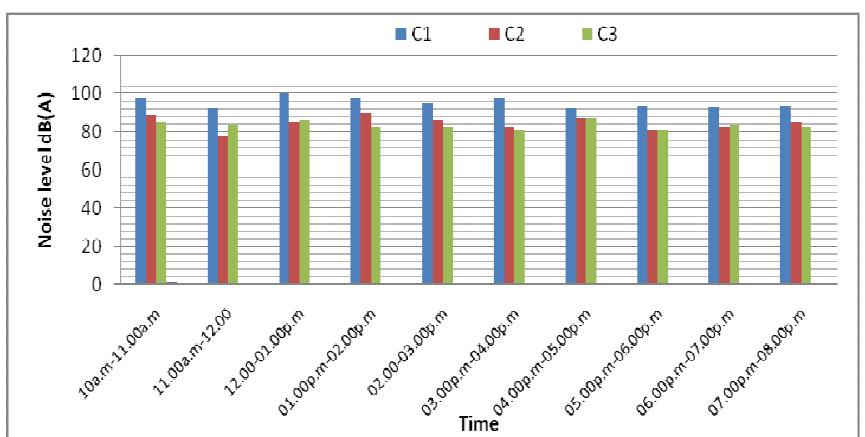

Figure5. Average ambient noise levels in dB (A) during September 2011(Commercial areas)

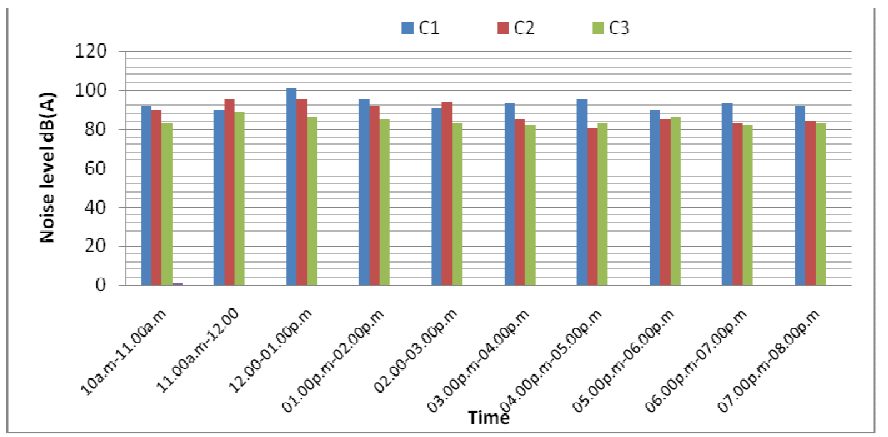

Figure6. Average ambient noise levels in $\mathrm{dB}(\mathrm{A})$ during October 2011(Commercial areas)

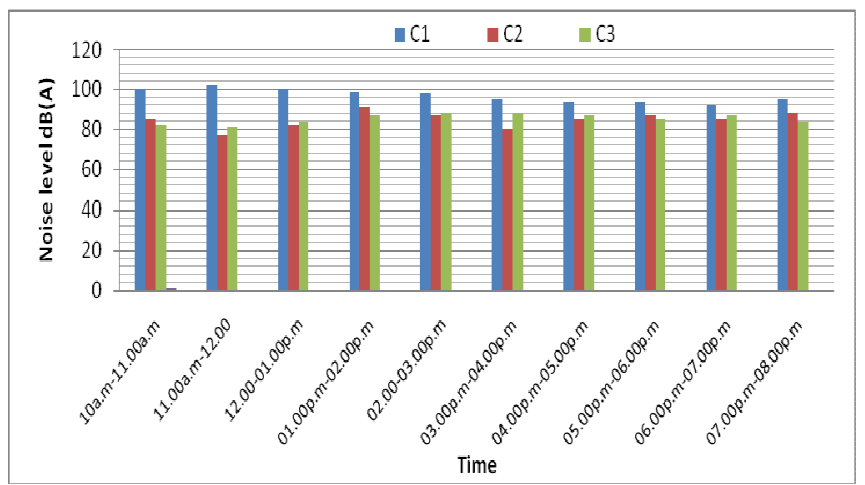

Figure7. Average ambient noise levels in $\mathrm{dB}$ (A) during November 2011(Commercial areas)

\subsection{Residential Zones}

The prescribed limit for the residential area is $55 \mathrm{~d} B$ (A) during daytime and $45 \mathrm{~d} B$ (A) during nighttime. None of the selected places of the residential zones in Chidambaram is recorded less than $55 \mathrm{~d} \mathrm{~B}(\mathrm{~A})$ during daytime. All the places had values that ranged between 54.33 and $84.6 \mathrm{~d} \mathrm{~B}(\mathrm{~A})$ at sirkazhi main road, 58.6 and $82.6 \mathrm{~d} \mathrm{~B}$ (A) at Omakulam and 57 and $75.6 \mathrm{~d} \mathrm{~B} \mathrm{(A)} \mathrm{at} \mathrm{Annamalai} \mathrm{University} \mathrm{campus} \mathrm{The}$ average noise level during September 2011, October 2011, and November 2011 is shown in figures 8, 9 and 10 respectively.

The various ambient noise parameter or noise indices, such as $\mathrm{L}_{10}, \mathrm{~L}_{50}, \mathrm{~L}_{90}, \mathrm{~L}_{\mathrm{eq}}, \mathrm{L}_{\mathrm{np}}, \mathrm{TN}$ and NC Were also computed. The average noise level indices in silence zone during September 2011 to November 2011 are shown in figure 11. The average noise level indices in commercial zone during September 2011 to November 2011 are shown in figure 12. The average noise level indices in residential zone during September 2011 to November 2011 are shown in figure 13.The average ambient noise parameters are given in table 5 .This table 5 shows the data for noise level indices for all the selected zones of Chidambaram town.

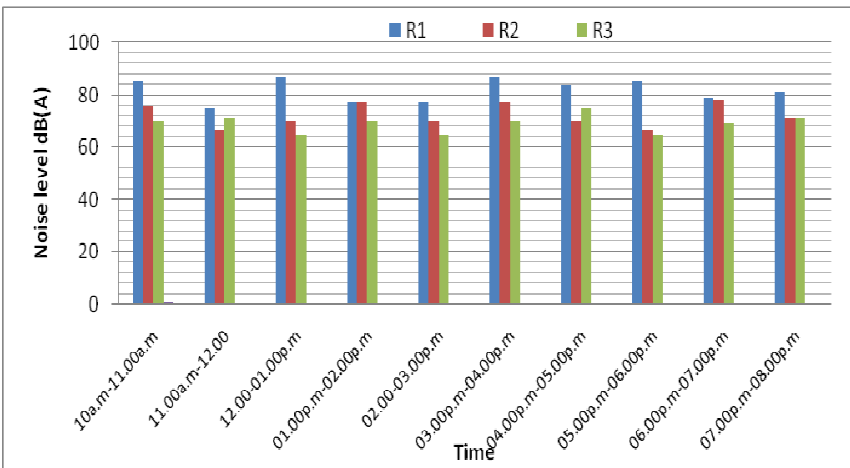

Figure 8 .Average ambient noise levels in $\mathrm{dB}(\mathrm{A})$ during September 2011(Residential areas)

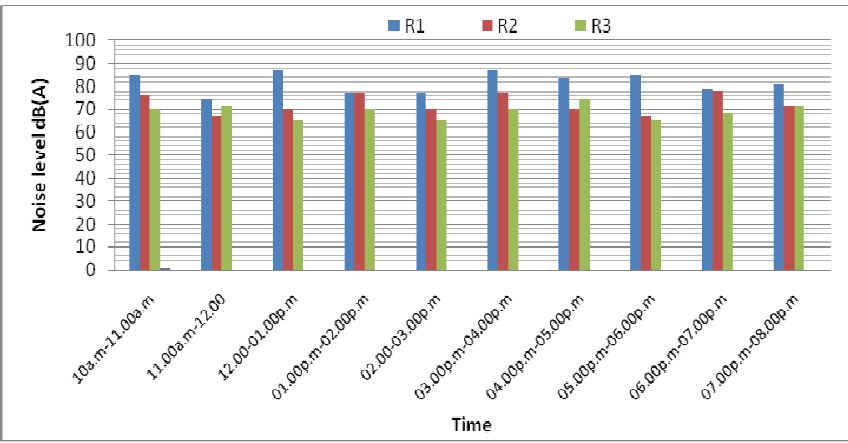

Figure 9.Average ambient noise levels in $\mathrm{dB}$ (A) during October 2011(Residential areas) 


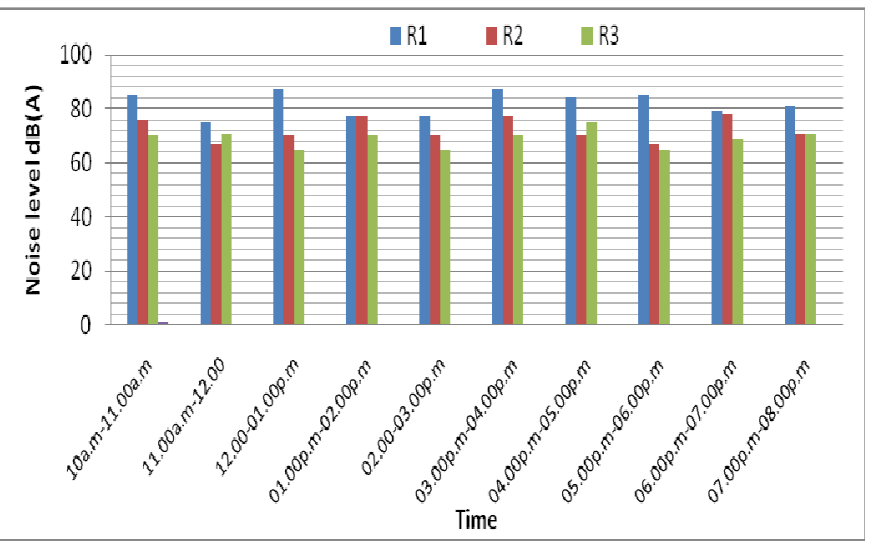

Figure 10.Average ambient noise levels in $\mathrm{dB}(\mathrm{A})$ during November 2011(Residential areas).

The table 4 shows the average noise levels and their variations with distance away from the roadsides.

Table 4 Average level of noise (Leq) in Chidambaram town

\begin{tabular}{|c|c|c|c|c|c|c|}
\hline \multirow[t]{2}{*}{ Time interval } & \multicolumn{6}{|c|}{ Distance from road side $(\mathrm{m})$} \\
\hline & 10 & 20 & 30 & 40 & 50 & 100 \\
\hline 10a.m-11.00a.m & 80.2 & 78.5 & $\begin{array}{l}74.3 \\
0\end{array}$ & $\begin{array}{l}72.5 \\
0\end{array}$ & $\begin{array}{l}68.5 \\
0\end{array}$ & $\begin{array}{l}60.3 \\
1\end{array}$ \\
\hline 11a.m-12.00 & 78.4 & 75.3 & 73.4 & $\begin{array}{l}70.4 \\
0\end{array}$ & $\begin{array}{l}65.3 \\
0\end{array}$ & 61.4 \\
\hline 12-1.00p.m & 81.4 & 80.2 & 78.3 & 75.0 & 72.0 & 68.3 \\
\hline $\begin{array}{l}1.00 \text { p.m- } \\
2.00 \text { p.m }\end{array}$ & 84.3 & 82.4 & 80.5 & 78.4 & 75 & $\begin{array}{l}70.1 \\
0\end{array}$ \\
\hline $\begin{array}{l}2.00 \text { p.m- } \\
3.00 \text { p.m }\end{array}$ & 75.5 & $\begin{array}{l}72.1 \\
0 \\
\end{array}$ & $\begin{array}{l}70.4 \\
0\end{array}$ & $\begin{array}{l}68.2 \\
0 \\
\end{array}$ & $\begin{array}{l}65.3 \\
0\end{array}$ & $\begin{array}{l}60.3 \\
0\end{array}$ \\
\hline $\begin{array}{l}3.00 \text { p.m- } \\
4.00 \text { p.m }\end{array}$ & 78.6 & 75.4 & 73.5 & 70.4 & 67.6 & 64.8 \\
\hline $\begin{array}{l}4.00 \text { p.m- } \\
5.00 \text { p.m }\end{array}$ & $\begin{array}{l}83.2 \\
0\end{array}$ & 80.6 & 76.5 & 74.9 & 70.6 & 68.4 \\
\hline $\begin{array}{l}5.00 \text { p.m- } \\
6.00 \text { p.m }\end{array}$ & 85.2 & 82.3 & 78.4 & 75.3 & 72.3 & 70.4 \\
\hline $\begin{array}{l}6.00 \text { p.m- } \\
7.00 \text { p.m }\end{array}$ & 82.3 & 80.2 & 76.8 & 74.6 & 71.5 & 69.4 \\
\hline $\begin{array}{l}7.00 \text { p.m- } \\
8.00 \text { p.m }\end{array}$ & 80.0 & $\begin{array}{l}76.1 \\
0\end{array}$ & 72.5 & 68.3 & $\begin{array}{l}65.2 \\
0\end{array}$ & 61.5 \\
\hline
\end{tabular}

\begin{tabular}{|c|c|c|c|c|c|c|c|c|c|c|}
\hline \multirow{2}{*}{$\begin{array}{l}\text { Site } \\
\mathrm{s}\end{array}$} & \multicolumn{10}{|c|}{ Average noise parameters dB(A) } \\
\hline & $\begin{array}{l}\text { Ma } \\
\text { x }\end{array}$ & $\begin{array}{l}\mathrm{Mi} \\
\mathrm{n}\end{array}$ & $\begin{array}{l}\text { Av } \\
\mathrm{e}\end{array}$ & $\begin{array}{l}\mathrm{L}_{1} \\
0 \\
\end{array}$ & $\begin{array}{l}\mathrm{L}_{5} \\
0 \\
\end{array}$ & \begin{tabular}{|l}
$\mathrm{L}_{9}$ \\
0 \\
\end{tabular} & $\begin{array}{l}\mathrm{L}_{\mathrm{e}} \\
\mathrm{q}\end{array}$ & $\mathrm{L}_{\mathrm{np}}$ & $\begin{array}{l}\mathrm{T} \\
\mathrm{N} \\
\end{array}$ & $\begin{array}{l}\mathrm{N} \\
\mathrm{C} \\
\end{array}$ \\
\hline \multicolumn{11}{|c|}{ Silence zone } \\
\hline S1 & 89 & 50 & $\begin{array}{c}69 . \\
5 \\
\end{array}$ & $\begin{array}{l}7 \\
3 \\
\end{array}$ & $\begin{array}{l}6 \\
8 \\
\end{array}$ & 60 & $\begin{array}{l}70 . \\
8 \\
\end{array}$ & $\begin{array}{c}83 . \\
8 \\
\end{array}$ & 82 & 13 \\
\hline S2 & 95 & 51 & 73 & $\begin{array}{l}7 \\
5\end{array}$ & $\begin{array}{l}6 \\
8\end{array}$ & 60 & $\begin{array}{c}71 . \\
7\end{array}$ & $\begin{array}{c}86 . \\
7\end{array}$ & 90 & 15 \\
\hline S3 & 52 & 42 & 47 & $\begin{array}{l}4 \\
8\end{array}$ & $\begin{array}{l}4 \\
4\end{array}$ & 38 & $\begin{array}{c}48 . \\
6\end{array}$ & $\begin{array}{c}54 . \\
6\end{array}$ & 32 & 10 \\
\hline
\end{tabular}

\begin{tabular}{|c|c|c|c|c|c|c|c|c|c|c|}
\hline S4 & 84 & 50 & 67 & $\begin{array}{l}7 \\
1\end{array}$ & $\begin{array}{l}6 \\
5\end{array}$ & 58 & $\begin{array}{c}67 . \\
8\end{array}$ & $\begin{array}{c}80 . \\
8\end{array}$ & 80 & 13 \\
\hline \multicolumn{11}{|c|}{ Commercial zone } \\
\hline $\mathrm{C} 1$ & 102 & 48 & 75 & $\begin{array}{l}7 \\
8 \\
\end{array}$ & $\begin{array}{l}7 \\
0\end{array}$ & 63 & $\begin{array}{c}73 . \\
7\end{array}$ & $\begin{array}{c}88 . \\
7\end{array}$ & 93 & 15 \\
\hline $\mathrm{C} 2$ & 97 & 51 & 74 & $\begin{array}{l}7 \\
6\end{array}$ & $\begin{array}{l}6 \\
8\end{array}$ & 62 & $\begin{array}{c}71 . \\
2\end{array}$ & $\begin{array}{c}85 . \\
2\end{array}$ & 88 & 14 \\
\hline $\mathrm{C} 3$ & 89 & 61 & 75 & $\begin{array}{l}7 \\
3 \\
\end{array}$ & $\begin{array}{l}6 \\
7\end{array}$ & 60 & $\begin{array}{c}69 . \\
8\end{array}$ & $\begin{array}{c}82 . \\
8\end{array}$ & 82 & 13 \\
\hline \multicolumn{11}{|c|}{ Residential zone } \\
\hline $\mathrm{R} 1$ & 87 & 51 & 69 & $\begin{array}{l}7 \\
2\end{array}$ & $\begin{array}{l}6 \\
3\end{array}$ & 58 & $\begin{array}{c}66 . \\
2\end{array}$ & $\begin{array}{c}80 . \\
2\end{array}$ & 84 & 14 \\
\hline $\mathrm{R} 2$ & 85 & 57 & 76 & $\begin{array}{l}7 \\
5\end{array}$ & $\begin{array}{l}6 \\
4\end{array}$ & 59 & $\begin{array}{c}68 . \\
2\end{array}$ & $\begin{array}{c}84 . \\
2\end{array}$ & 93 & 16 \\
\hline R3 & 80 & 54 & 67 & $\begin{array}{l}7 \\
1\end{array}$ & $\begin{array}{l}6 \\
0\end{array}$ & 58 & $\begin{array}{c}62 . \\
8\end{array}$ & $\begin{array}{c}75 . \\
8\end{array}$ & 80 & 13 \\
\hline
\end{tabular}

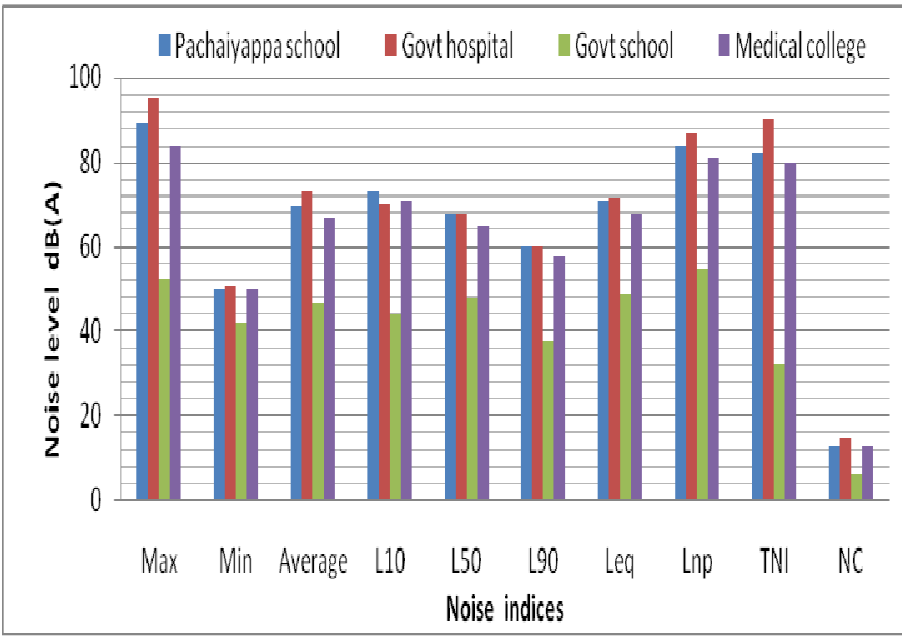

Figure 11.Average Ambient Noise Parameters-Sensitive areas

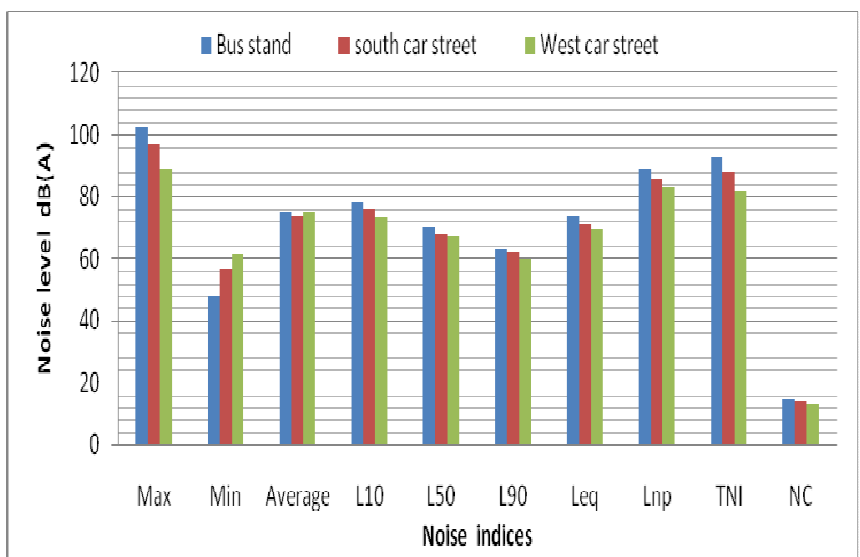

Figure 12.Average Ambient Noise Parameters-Commercial areas 


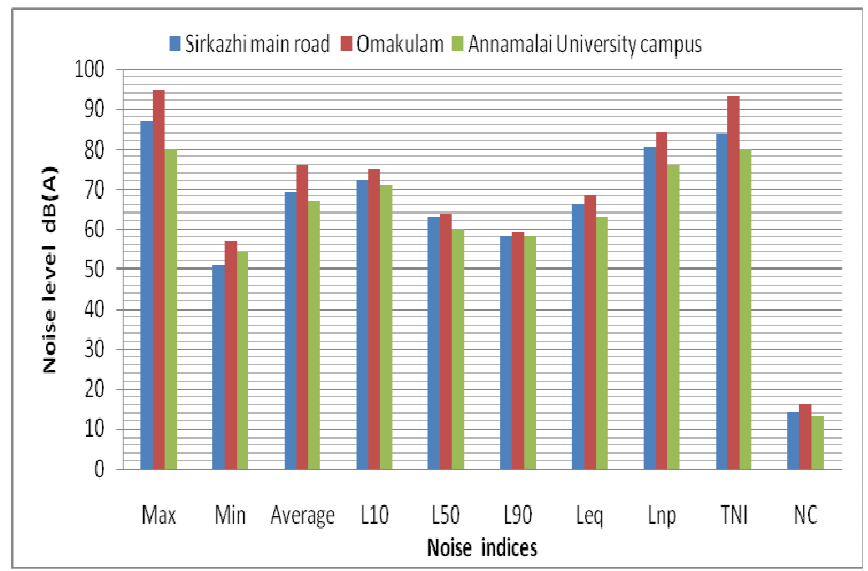

Figure 13.Average Ambient Noise Parameters-Residential areas

\section{CONCLUSIONS}

The honking of horns, flow of ill-maintained vehicles and poor road conditions on roadsides that cause traffic congestion were found to be the reasons for high noise level in Chidambaram town. People in general, patients and students in particular are highly exposed to noise level. Residential areas are too exposed to the high noise level. The study also concludes that:

1. Majority of the people are not wearing hearing protective equipments Main reasons were their negligence, feeling of un- comfortableness.

2. Almost all the people are highly exposed to high noise levels [>60 dB (A)], without proper ear protection.

Following measures need to be taken to tackle the situation:
a) . Ban on use of horns.
b) . Proper maintenance of roads
c) . Removal of road side encroachments
d) . Planting of recommended plant species
e) The implementation of the technical measures for noise levels.

The following conclusions were obtained from our study.Maxixmum noise level of 101d B (A) is observed at Bus stand in the morning time and minimum noise level of $44 \mathrm{~d} \mathrm{~B}$ (A) is observed at government higher secondary school in the afternoon.

The results of this study show that the level of noise pollution in Chidambaram town far exceeds the acceptable limits set by the CPCB.Even in the residential areas and vulnerable institutions like schools and hospitals, noise is much higher than the acceptable limit. This has serious implication on the general health and wellbeing of the inhabitants of the Chidambaram town. It is also observed that noise level is closed related with the number of motor vehicles. Urgent measures should be taken to control the level of noise pollution in the town.

\section{REFERENCES}

[1]. Banerjee D, Chakraborty SK (Dept Env Water Manag, BB Coll, Ushagram, Asansol 713303, Burdwan). Monthly variation in nighttime noise levels at residential areas of Asansol city (India). Journal of Environmental Sci Engng, 48(1) (2006), 39-44 [3 Ref]

[2]. Jeba Rajasekhar RV, Daniel Tennyson, Vijay Bhaskar B, Muthusubramanian P (Dept Env Sch Energy Sci, Madurai Kamaraj Univ, Madurai 625021). Estimated and predicted noise levels in Madurai city. Asian J Microbio, Biotechno Environ Sci, 7(4) (2005), 771-774 [10 Ref].

[3]. Kisku GC, Sharma Kailash, Kidwai MM, Barman SC, Khan AH, Singh Ramesh, Mishra Divya, Bhargva SKC (Environ Monit Sec, Indl Toxico Res Cent, Lucknow 226001). Profile of noise pollution in Lucknow city and its impact on environment $J$ Environ Bio, 27(2 Suppl) (2006), 409- 412 [19 Ref].

[4]Pachpande BG, Patel VS, Patil RD, Girase MR, Ingle ST (Sch Environ Sci, North Maharashtra Univ, Jalgaon 425001). Assessment of hearing loss in school teachers and students exposed to highway traffic noise pollution. $J$ Ecophysio Occupl Hlth, 5(1\&2) (2005), 123-126 [13 Ref]

[5]Thakur Gulab Singh (Dept Chem, Shri MM Coll Sci, Sakkardara Chowk,Umrer Rd, Nagpur . A study of noise around an educational institutional area $J$ Environ $S c i$ Engg, 48(1) (2006), 35-38 [5 Ref]

[6]Thangadurai N, Ravichandran C, Meena K (Dept Geo, Anna Univ, Chennai 600025). Environmental noise pollution in Salem, Tamil Nadu, India. J Indl Polln Contl, 21(2) (2005), 347-354 [21 Ref]

[7]Tiwari Divya, Shukla M (Dept Bot, ANDNNAM Mahila Mahavidyalaya, Kanpur 208002). Study of noise levels at Kanpur with respect to various noise indices. Nature Env Polln Techno, 5(3) (2005), 438-488 [16 Ref]

[8]. Evans, G.W, and Cohen, S. Environmental stress. In D. Stokols and I.Altman (Eds), Handbook of environmental psychology (1987) New York Wiley571-610

[9]. Ravichandran, C, Chandrasekaran, G.E. andMadhu, S. The status of noise pollution in Tiruchirapalli city Indian J.Env.Prot., (1997) 17(11), 806-808

[10]. Ravichandran, C, Chandrasekaran, G.E.and Venkatsubramanian, R, Status of noise pollution in Hosur. Indian J.Env.Prot., (1997) 18(4)278-280.

[11]. Tandoon, N., and H. Pandey, Noise levels of some vehicles and traffic noise level at some road Crossings in South Delhi. Indian J Env.prot. (1998), 18(6)454-458.

[12]. Raja, R.E., Ravichandran, C., and Sagila, C.S. An assessment of noise pollution due to automobiles in Cuddalore, Tamilnadu Indianj Environ (1999), M., 41(4)312316 
[13].CPCB. (1995). Pollution control acts, rules, and notifications issued there under Pollution control series: PCL/2/1992, (Volume I) New Delhi: Central pollution control board.

[14]. Agarwal, S. and Tiwari, S.L., susceptibility level of few plants on the basis of air pollution tolerance index, Ind forester, (1997) 4,319-322.

[15]. Kumar, S and Paulsany, S. Studies on identification of suitable tree species for control of effect of air pollution in TamilNadu. Nat Env and Poll tech., (2006) 5(4) 591-599.

[16]. Paulsanmg, S and Latha, N. Evaluation of air pollution tolerant tree species in Coimbatore city. JEcol.Res. Biocon, (2000), (2), 20-23. 